\title{
Teesejä ja vastakkaisargumentteja työn ja oppimisen murroksesta
}

Jaakko Virkkunen \& Heli Ahonen (2007). Oppiminen muutoksessa. Uusi väline työyhteisön oppimiskäytäntöjen uudistamiseen. Vantaa: Infor Oy. 144 sivua

\begin{abstract}
K äsitykset osaamisesta, oppimisesta ja kehittämisestä ovat peräisin vakaalta massatuotannon aikakaudelta 1900-luvun alusta. Nopeasti muuttuvassa markkinoiden ja informaation maailmassa on kehittymässä uusi työn tyyppi, yhteiskehittelytyö (Engeström 2006), jossa tarvitaan erilaista oppimista ja osaamisen johtamista.
\end{abstract}

Arvioitavassa kirjassa kuvataan Elisa Oyj:n ja Helsingin yliopiston kehitystyötä, jossa rakennettiin ja testattiin uutta osaamisen johtamisen, organisaation oppimiskäytäntöjen uudistamisessa käytettävää Muutoslaboratorio-välinettä ja siihen kytkeytyvää toiminnan teoriaa ja ekspansiivista oppimista. Liiketoiminnan kehityshaasteet tulevat esille käytännön häiriöinä ja laboratoriossa työyhteisö itse selvittää (muutoslaboratorio-ohjaajan avulla), miten hyvin nykyiset toimintatavat ja oppimiskäytännöt vastaavat toiminnan ajankohtaisiin haasteisiin sekä tuottaa uusia työhön kytkeytyviä oppimiskäytäntöjä, joilla työn hallintaa voidaan parantaa.

Kun työ muuttuu, muuttuu myös oppiminen. Kirjoittajat tekevät ymmärrettäväksi työn ja oppimisen murroksen. Tulokset tiivistetään sekä muutoslaboratoriomenetelmän käytön teeseinä että kuutena kärjistettynä vastakkain asetettuna argumenttina. Lukijalle tarjotaan haasteellista ajateltavaa, kuten seuraavat esimerkit havainnollistavat.

Esimerkkejä teeseistä: Osaamisalueiden kuvaamisesta on siirryttävä oppimisen prosessien ja menetelmien erittelemiseen ja kehittämiseen, koska osaamiskartoitukset eivät monestikaan kuvaa tapaa, jolla osaaminen tuotetaan. Toisen teesin mukaan on tunnistettava organisaation oppimiskäytäntöjä ja kehitettävä niitä kahdesta suunnasta; virallisesta koko organisaation oppimisinfrastruktuurista käsin sekä epävirallisesta työkäytäntöihin liittyvistä paikallisista oppimiskäytännöistä käsin. Kolmannen teesin mukaan on hallittava monen eri aikajänteen muutoksia samanaikaisesti. Osaamisen johtamisessa on lähdettävä oppimisesta, joka kytkeytyy toimintakonseptin muutokseen. Toimintakonseptin muutokset eivät kuitenkaan ole selvärajaisia. Tiedon ja osaamisen johtamisessa onkin kyettävä hallitsemaan samanaikaisesti sekä pitkäjänteistä toimintakonseptin uudistamista että nopeita, ajankohtaisen tilanteen vaatimia muutoksia.

\section{$\mathrm{V}$} astakkain asetetut argumentit kuvaavat aineksia, joiden avulla uuden osaamisen johtamista koskevan näkemystä voi kehitellä. Näitä ovat:

1. Tiedon hallinta vai toimintakäytäntöjen uudistaminen? Tiedon kehittymisessä on aina kysymys myös toimintakäytäntöjen kehittymisestä. Ja kääntäen, toiminnan kehittyminen luo uusia tiedon muodostumisen ja oppimisen edellytyksiä. Yhteisten toimintakäytäntöjen kriittinen analyysi tuottaa tietoa toiminnan kehityshaasteista ja vastaamismahdollisuuksista, samalla se luo motiivia uudistaa toimintaa.

2. Tavoite vai kehityshaaste? Massatuotannon johtamisessa ja prosessien parantamisessa täsmälliset tuotantotavoitteilla on suuri merkitys. Täsmälliset tavoitteet ovat uudistamistyössä ongelmallisia. Ja samalla on mahdollista olla määrätietoinen. Mihin määrätietoisuus perustuu? Toiminnan uudistamisessa on opittava asioita, joita ei vielä ole olemassa ja joita ei siksi voida täsmällisesti kuvata.

3. Käytäntöyhteisö vai yhteinen toimijuus? Käytäntöyhteisökeskustelussa korostetaan sosiaalisia suhteita ja henkilöiden keskinäistä tuntemusta ja luottamusta. Kirjoittajien mukaan käytäntöyhteisö ei kuitenkaan auta ymmärtämään, miten toiminta ja sen yhteisörakenteet uudistuvat. On kuitenkin havaittu, että sosiaalisiin suhteisiin perustavan yhteisöllisyyden lisäksi on myös yhteisen toiminnan ja kiinnostuksen kautta syntyvää yhteisöllisyyttä, yhteisen kohteen välittämää yhteisöllisyyttä.

4. Koulutus ja opiskelu vai oppijärjestelmän ja oppimiskäytäntöjen kehittäminen? Henkilöstön kehittäminen on tulevaisuudessa sidoksissa kollektiivisesti käytettäviin ja kehitet- 
täviin yhteisiin välineistöihin, oppimisen infrastruktuureihin. Osaamisen johtamisessa tulisi kiinnittää erillisten oppimisympäristöjen sijasta huomiota koko tuotantoon kytkeytyvän oppimisen järjestelmään ja erilaisiin oppimiskäytäntöihin.

5. Välineistön vain toiminnan yhteisen kohteen hallinta? Kun osaamiskartoituksissa pyritään usein vastaamaan kysymykseen, mitä kunkin työntekijän pitäisi osata, vastaukseksi saadaan yleensä teknologioihin, järjestelmiin, välineisiin ja menetelmiin liittyviä tietoja koulutustarpeita. Kysymys voidaan asettaa toisinkin: erittelemällä toiminnan kohteesta ja kohteen hallinnassa esiintyviä häiriöitä ja katkoksia etsitään vastausta kysymykseen: Miltä osin toimintaa ei hallinta ja miten sitä voitaisiin yhdessä hallita paremmin? Kun käsityömäisestä tuotannosta ja vakaissa oloissa toteutettavan massatuotannon olosuhteista siirrytään prosessien jatkuvaan parantamiseen, osaamisen ylläpito ja kehittäminen siirtyvät tilaus-,toimitus prosessien yhteistoiminnalliseen hallintaan. Se edellyttää yksilöiltä perustietoja ja taitoja, mutta perustuu enemmän prosessien häiriöiden syiden yhteiseen erittelyyn ja yhteistoimintakäytäntöjen parantamiseen. Oppiminen perustuu yhteistyöosapuolten keskinäisiin neuvotteluihin ja toimivien ratkaisujen yhteiseen kehittämiseen.

6. Muutoksen vai toiminnan ekspansiivisen kehityksen johtaminen? Toimintakonseptin muutos ja laaja, monitahoinen ja ristiriitainen muutos- ja kehitysprosessi. Ekspansiivisen oppimisen mallin avulla on mahdollista hahmottaa tapahtumasarjaa, jossa muutokset tarpeet ja edellytykset kehittyvät asteittain. Muutoksen toteuttaminen on sidoksissa ulkoisissa toimintaolosuhteissa tapahtuviin muutoksiin ja edellyttää monia toisiaan täydentäviä uudistuksia. Ekspansiivisen oppimisen malli suuntaa huomion kehitysprosessin eri vaiheille tyypillisiin toiminnan sisäisiin ristiriitoihin ja kehitysaskelten ottamisen edellytysten vähittäiseen kypsymiseen.

Kirjoittajat päättävät teoksen korostamalla, että kehityksen ohjaamisen kannalta on tärkeää tunnistaa toiminnan keskeiset kehityshaasteet, ei niinkään täsmällisinä tavoitteina, vaan pikemminkin tärkeiden kilpailevien tavoitteiden tai vaatimusten ristiriitoina. Lisäksi tarvitaan käytännön kokeiluja, jota auttavat löytämään tavan ylittää toiminnan kulloinkin ajankohtaiset kehitysristiriidat.

\section{SUSANNA}

GARDEMEISTER 